\title{
Immunological and Immunoassay Studies of the Binding Protein for Vitamin D and Its Metabolites in Human Serum
}

\author{
Michio ImaWari and DeWitT S. Goodman \\ From the Department of Medicine, Columbia University College of Physicians and Surgeons, New \\ York 10032
}

A B S TRACT This study reports the development of a specific and sensitive radioimmunoassay and a simple and accurate radial immunodiffusion (RID) assay for the human serum-binding protein for vitamin $\mathrm{D}$ and its metabolites (DBP). These immunoassays employed a monospecific antiserum that was prepared in rabbits against human DBP. The radioimmunoassay effectively measured DBP in amounts of $1-10 \mathrm{ng}$, whereas the RID assay measured DBP accurately in amounts of $0.2-0.8 \mu \mathrm{g}$. The results obtained with the two immunoassays on the same samples of serum agreed well with each other. Using the RID assay, the mean $( \pm \mathrm{SD})$ serum DBP concentration observed in 35 normal persons was $422 \pm 27 \mu \mathrm{g} / \mathrm{ml}$. Generally similar levels were observed in 66 hyperlipidemic subjects. In molar terms, the mean DBP concentration (approximately $8 \mu \mathrm{M}$ ) was of the order of 50 times the usual serum level of 25-hydroxyvitamin D (25OH-D) plus vitamin D. Thus, most of plasma DBP circulates as apo-DBP, not containing a bound molecule of 25-OH-D or of vitamin D. DBP and 25-OH-D concentrations were measured in a limited number of patients with hypercalcemia, mild hypocalcemia, and markedly elevated serum 25-OH-D levels due to oral vitamin $\mathrm{D}$ supplementation. It was found that major changes can occur in the serum levels of 25-OH-D and of calcium with very little or no associated changes occurring in the serum concentration of DBP. The results suggest that neither serum 25-OH-D nor serum calcium plays an important role in the regulation of the metabolism of DBP. Data were obtained that confirmed and extended an earlier report on the identity of the group-specific component $(\mathrm{Gc})$ protein in plasma with the plasma vitamin $\mathrm{D}$-binding protein. On immunodiffusion against whole serum, the line formed with the anti-DBP antiserum showed a complete reaction-of-identity with the line formed with

Received for publication 10 June 1976 and in revised form 1 November 1976. commercial antiserum against Gc protein. Furthermore, serum that had been depleted of DBP by treatment with Sepharose containing covalently coupled antibodies against DBP was found to be depleted also of immunoreactivity against anti-Gc protein antiserum. In addition, the properties of the purified DBP preparation agreed closely with those previously reported by others for Gc protein. Finally, a comparative immunology study showed that sera from several different mammalian orders showed some immunoreactivity against the antihuman DBP antiserum. Thus, proteins immunologically similar to human DBP are present in sera from a number of mammalian species and orders.

\section{INTRODUCTION}

Vitamin D and its hepatic metabolite, 25-hydroxyvitamin $\mathrm{D}$, are transported in human plasma bound to a specific transport protein, the binding protein for vitamin $\mathrm{D}$ and its metabolites (DBP).' We have recently reported the isolation and partial characterization of human DBP (1). Purified DBP was homogeneous in the analytical ultracentrifuge, and had a sedimentation constant of $3.49 \mathrm{~s}$ and a mol wt $\cong 52,000$. The isoelectric point of DBP was estimated as 4.8. Direct study of the binding capacity of DBP for added 25-hydroxyvitamin $\mathrm{D}_{3}$ $\left(25-\mathrm{OH}-\mathrm{D}_{3}\right)$ showed that the isolated DBP had a high affinity for 25-(OH-D $\mathrm{D}_{3}$, with an apparent maximum binding capacity of one molecule of $25-\mathrm{OH}-\mathrm{D}_{3}$ per molecule of protein.

We now report the development of a specific radioimmunoassay and a radial immunodiffusion assay for

\footnotetext{
${ }^{1}$ Abbreviations used in this paper: DBP, binding protein for vitamin D and its metabolites; Gc protein, group-specific component protein; 25-OH-D, 25-hydroxyvitamin D; PBS, phosphate buffered saline $(0.01 \mathrm{M}$ potassium phosphate buffer, $\mathrm{pH} 7.4,0.15 \mathrm{M} \mathrm{NaCl}$ ); $\mathrm{RBP}$, retinol-binding protein; RID, radial immunodiffusion.
} 
human DBP. With these immunoassays, the levels of DBP in the serum of normal persons and in patients with various clinical disorders were determined. The relationships between the serum levels of DBP and 25-OH-D were also explored. Immunological identity between DBP and the group-specific component $(\mathrm{Gc})$ proteins in plasma was demonstrated, in support of the conclusion of a recent report by Daiger et al. (2). Some of these findings have been reported in abstract form (3).

\section{METHODS}

Human DBP. DBP was isolated from plasma as described previously (1). The preparation of purified DBP used in the studies reported here was the same preparation we described and partially characterized in our previous publication (1).

Preparation of antiserum. An antiserum against human DBP was raised in a white rabbit weighing $2.4 \mathrm{~kg}$. $1.5 \mathrm{mg}$ DBP was dissolved in $0.75 \mathrm{ml}$ of $0.1 \mathrm{M}$ potassium phosphate buffer, $\mathrm{pH}$ 7.4, and the solution was emulsified with an equal volume of complete Freund's adjuvant (Difco Laboratories, Detroit, Mich.). Immunization was carried out as described previously for the preparation of a rabbit antiserum against rat retinol-binding protein (4). 2 wk after the booster injection, and at weekly intervals thereafter, blood was collected from ear veins or arteries. After clotting, the blood samples were centrifuged at $1,500 \mathrm{rpm}$ for $20 \mathrm{~min}$ at $4^{\circ} \mathrm{C}$, and the sera were collected and stored at $-60^{\circ} \mathrm{C}$.

Double immunodiffusion in gel studies of this antiserum showed that it was not monospecific and displayed two major precipitin lines when reacted against human whole serum. Only one precipitin line was seen on immunodiffusion of this antiserum against the purified DBP preparation, and this major precipitin line showed a reaction-of-identity with one of the two lines obtained with whole serum. After drying and staining the immunodiffusion gel, however, a faint minor precipitin line was also seen after double diffusion of this antiserum against the purified DBP preparation.

The immunogen responsible for the formation of the second (contaminating) precipitin line (not containing DBP) was identified by immunodiffusion studies in which this antiDBP antiserum and each of several other available antisera were reacted together against human whole serum. The sera tested included rabbit antisera against the following human plasma proteins: $\alpha_{1}$-antitrypsin, $\alpha_{1}$-acid glycoprotein, inter- $\alpha$-trypsin inhibitor, $\alpha_{2}$-HS glycoprotein (all purchased from Behring Diagnostics, American Hoechst Corp., Somerville, N. J.), and corticosteroid-binding globulin (a gift from Dr. William Rosner, Roosevelt Hospital and the Columbia University College of Physicians and Surgeons, New York). The second precipitin line obtained on immunodiffusion of the anti-DBP antiserum against whole serum showed a reaction-of-identity with the precipitin line obtained with the anti- $\alpha_{1}$-antitrypsin antiserum.

A monospecific antiserum against human DBP was raised in other rabbits by injecting them with precipitin lines containing the DBP and rabbit immunoglobulin. The precipitin lines used for this purpose were prepared by immunoelectrophoresis of a solution of the isolated DBP preparation, which resulted in a wide separation of the major precipitin line against DBP from the minor contaminating precipitin line (see Fig. 1).

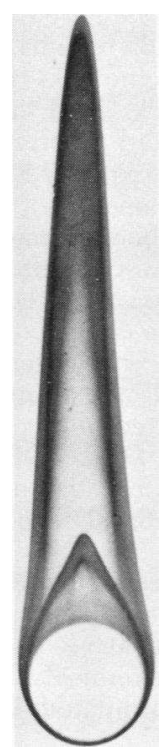

FIGURE 1 Immunoelectrophoresis, with the Laurell rocket technique, of a solution of the purified DBP preparation, using agarose gel containing the first (not monospecific) rabbit antiserum prepared against DBP (see Methods for details). The actual size of the well was $4 \mathrm{~mm}$ in diameter (10 $\mu$ l capacity). The gel shown here was washed, stained with Coomassie Brilliant Blue, and dried. The major rocket seen represents the immunoprecipitin line formed between DBP and anti-DBP antibodies. The small rocket close to the well represents the contaminating precipitin line.

Gels were prepared for immunoelectrophoresis with 14 $\mathrm{ml}$ of $1 \%$ agarose containing $5 \%$ of the anti-DBP antiserum, in barbital buffer, $\mathrm{pH} 8.6$, ionic strength 0.02 . Gels were poured on $8.4 \times 8.4-\mathrm{cm}$ glass plates initially precoated with a layer of $0.2 \%$ agarose in water which were then air dried. Eight wells (diameter, $4 \mathrm{~mm}$ each) per plate were punched out using a template for Laurell rocket immunoelectrophoresis (LKB Instruments, Inc., Rockville, Md.) (5). $10 \mu \mathrm{l}$ of DBP solution $(0.5$ $\mathrm{mg} / \mathrm{ml}$ in $0.02 \mathrm{M}$ potassium phosphate buffer, $\mathrm{pH} 7.4$, with $0.15 \mathrm{M} \mathrm{NaCl}$ ) was added to each well. Electrophoresis was carried out with barbital buffer, $\mathrm{pH} 8.6$, ionic strength 0.02 , at a constant voltage of $280 \mathrm{~V}$ (approximately $36 \mathrm{~mA}$ for two plates) at $4^{\circ} \mathrm{C}$ for $3 \mathrm{~h}$. At the end of electrophoresis, each well showed a major rocket precipitin line, representing the antigen-antibody complex between DBP and anti-DBP antibodies, and a small minor contaminating rocket line, as shown in Fig. 1. The gels were washed with phosphate-buffered saline $(0.01$ $\mathrm{M}$ potassium phosphate buffer, $\mathrm{pH} 7.4,0.15 \mathrm{M}$ $\mathrm{NaCl}$ ) (PBS) containing $0.01 \% \mathrm{NaN}_{3}$ for 3 days, with change of washing buffer $(250 \mathrm{ml} /$ plate $)$ three times per day, and were then washed with PBS without $\mathrm{NaN}_{3}$ for 1 day and partially dried in air for $1.5 \mathrm{~h}$. The rocket precipitin lines containing DBP were cut out with a scalpel and divided into three lots in three vials; two vials were stored at $-20^{\circ} \mathrm{C}$ until used later for booster injections and one vial was used immediately.

The precipitin lines in one vial were emulsified with complete Freund's adjuvant and prepared for injection as described previously $(6,7)$. Two white rabbits, weighing $2.1 \mathrm{~kg}$ each, were each injected with $1 \mathrm{ml}$ of the resulting 
emulsion intramuscularly into the thigh and with $0.6 \mathrm{ml}$ subcutaneously in both scapula regions. Immediately thereafter, $0.5 \mathrm{ml}$ of pertussis vaccine was injected subcutaneously in the back of the neck. Each rabbit received booster injections of the emulsified precipitin lines 2 wk later $(0.1$ $\mathrm{ml}$ into each of four toe pads, $0.5 \mathrm{ml}$ into the right thigh muscle, and $1 \mathrm{ml}$ subcutaneously), and one of the two rabbits received additional booster injections 2 wks after that. Both rabbits were bled weekly after the last booster injection, and the serum was collected and stored at $-60^{\circ} \mathrm{C}$. 14 and 17 lots of sera were collected from the two rabbits, respectively, during a 4-5-mo interval. One of these lots of monospecific anti-DBP antiserum was used in all of the subsequent studies reported in this paper.

Radioimmunoassay of DBP. DBP (2.3 $\mu \mathrm{g}$ dissolved in PBS) was iodinated with ${ }^{125}$ I enzymatically with lactoperoxidase (Calbiochem, San Diego, Calif.), according to the method of Miyachi et al. (8). Carrier-free ${ }^{125} \mathrm{I}-\mathrm{Na}(200$ $\mathrm{mCi} / \mathrm{ml}$ ) was purchased from New England Nuclear, Boston, Mass. ${ }^{125}$ I-labeled DBP was separated from inorganic ${ }^{125} \mathrm{I}$ by gel filtration on a small $0.8 \times 10$-cm column of Sephadex G-75 (Pharmacia Fine Chemicals, Piscataway, N. J.). The specific activity of the iodinated DBP was usually of the order of $100 \mu \mathrm{Ci} / \mu \mathrm{g}$.

Before the development of the radioimmunoassay, a study was conducted to estimate the antibody titer of the antiDBP antiserum and to determine the appropriate dilution of antiserum for use in the immunoassay. It was determined that at a final dilution of 1:25,000 of antiserum, from 40 to $50 \%$ of the ${ }^{125}$ I-DBP (in the amount used in the radioimmunoassay, see below) was bound to antibody in the absence of added unlabeled DBP.

The radioimmunoassay procedure employed PBS containing $0.1 \% \mathrm{NaN}_{3}$ and $2.5 \%$ normal rabbit serum as buffer solution for all dilutions. Reagents were added to $1.0 \times 7.5$ $\mathrm{cm}$ tubes in the following order: (a) $150 \mu \mathrm{l}$ diluting buffer, (b) $50 \quad \mu l \quad 0.1 \mathrm{M}$ EDTA (Na salt), pH $7.4 ;(c)$ a $100-\mu$ l sample to be assayed (suitably diluted serum or standard DBP solution); (d) $100 \mu \mathrm{l}{ }^{125} \mathrm{I}-\mathrm{DBP}$, about 10,000 cpm; and $(e) 100 \mu \mathrm{l}$ anti-DBP antiserum, diluted 1:5,000 to give a final dilution of $1: 25,000$. After incubation in the dark at $4^{\circ} \mathrm{C}$ for 3 days, antibody-bound and free ${ }^{125} \mathrm{I}-\mathrm{DBP}$ were separated by precipitating the immunoglobulin with polyethylene glycol, $6,000-7,500 \mathrm{~mol}$ wt (Matheson, Coleman and Bell, Norwood, Ohio), as suggested by Desbuquois and Aurbach (9). To the $0.5 \mathrm{ml}$ of assay mixture in each tube, $1.5 \mathrm{ml}$ of $16 \%$ (wt/vol) polyethylene glycol in PBS containing $0.8 \mathrm{mg} / \mathrm{ml}$ of normal rabbit $\gamma$-globulin (Miles Laboratories, Inc., Elkhart, Ind.) was added. After mixing with a Vortex mixer (Scientific Industries, Inc., Queens Village, N. Y.) the tubes were centrifuged at $8,000 \mathrm{rpm}$ for $15 \mathrm{~min}$ at $4^{\circ} \mathrm{C}$. The supernates were immediately aspirated and the precipitates were assayed for ${ }^{125} \mathrm{I}$ in a Packard model 5219 Auto-Gamma counter (Packard Instrument Co., Inc., Downers Grove, Ill.) Calculations were made on a Wang model 700A programmable calculator (Wang Laboratories, Inc., Tewksbury, Mass.) by the logit-log method (10).

Using ${ }^{125}$ I-DBP alone, with no added unlabeled DBP and with the method described, $40-50 \%$ of added ${ }^{125}$ I was recovered in the precipitate (i.e., antibody-bound). With excess antibody (1:50 final dilution of anti-DBP antiserum), $97 \%$ of the ${ }^{125} \mathrm{I}$ was found in the precipitate. When nonimmune, normal rabbit serum was added instead of the anti-DBP antiserum (at a final dilution of 1:50), only $6.5 \%$ of the ${ }^{125} \mathrm{I}$ was recovered in the precipitate, representing the small amount of nonspecific precipitation of ${ }^{125} \mathrm{I}-$ DBP in the assay as used.
Radial immunodiffusion assay of DBP. A single radial immunodiffusion (RID) assay for DBP in human serum was developed according to the method of Mancini et al. (11) with some modifications. Immunodiffusion plates were prepared using $3.5 \mathrm{ml}$ of $1 \%$ agarose containing $2 \%$ rabbit anti-DBP antiserum in PBS with $0.1 \% \mathrm{NaN}_{3}$ per plate. Gels were poured on $2.4 \times 7.2$-cm diffusion plates (ImmunoPlate, Hyland Div., Travenol Laboratories, Inc., Costa Mesa, Calif.). 12 wells, each with a $2-\mathrm{mm}$ diameter were punched out per plate. $5-\mu l$ standards or samples to be assayed were applied into the wells and the plates were kept in a humid chamber. About 48 h later, when no further extension of precipitin rings was observed, the diameter of each precipitin ring was measured using a magnifying comparator (Meloy Laboratories, Inc., Springfield, Va.). A standard curve was prepared by plotting the square of the diameter of the precipitin ring against the known amount of DBP added to the well for each sample of a series of dilutions of a solution of purified DBP. The resulting plot was linear and could be used as an effective immunoassay with amounts of DBP added per well in the range of $0.2-0.8 \mu \mathrm{g}$.

The standard used for most RID assay runs was a sample of normal human whole serum which was standardized against purified DBP dissolved in PBS. The standard whole serum $(0.45 \mathrm{mg}$ of DBP per $\mathrm{ml})$ was diluted $3: 7(\mathrm{vol} / \mathrm{vol})$ with PBS, divided into small portions, and stored at $-20^{\circ} \mathrm{C}$. For each assay run, several dilutions of the standard whole serum were prepared from one freshly thawed portion, and these samples were used to provide the standard curve for that assay run.

Serum samples for RID assay were diluted 1:4 (vol/vol) with PBS before assay. Samples were routinely assayed in duplicate, and the mean of the pair of values was taken as the final value.

The recovery of DBP in the RID assay was determined by assaying a series of mixtures of a sample of normal serum and of a solution of purified DBP. For this study, the normal serum was diluted 1:4 with PBS, and the purified DBP was dissolved in PBS at a concentration of 0.109 $\mathrm{mg} / \mathrm{ml}$. Portions of these two solutions were mixed in different ratios to make five samples for study. The recovery of pure DBP in the assay was estimated by subtracting the DBP added with the serum in each sample from the total amount of immunoreactive DBP observed.

Assay for serum 25-OH-D. Serum 25-OH-D levels were determined by a competitive protein-binding assay, using normal diluted $(1: 4,000)$ human serum as the source of binding protein. The assay was generally similar to competitive protein-binding assays reported by others (12-16), except that the reported assays have used other sources of binding proteins, including kidney cytosol from rachitic rats (12), serum from normal $(13)$ and rachitic $(14,15)$ rats, and plasma from an osteomalacic man (16). Serum was extracted by shaking the $0.5-\mathrm{ml}$ sample with $2 \mathrm{ml}$ of ethanol and $3 \mathrm{ml}$ of hexane; phase separation was achieved by adding $2 \mathrm{ml}$ of water and centrifuging. The hexane phase was collected and the residue was re-extracted with $3 \mathrm{ml}$ hexane. After evaporation of the combined hexane phases to dryness, the lipid extract was chromatographed on a $1 \times 20-\mathrm{cm}$ column of Sephadex LH-20 (Pharmacia Fine Chemicals) (17) using chloroform:hexane, $1: 1(\mathrm{vol} / \mathrm{vol})$ as eluate. The first $20 \mathrm{ml}$ of eluate was discarded and the second $20 \mathrm{ml}$, containing 25-OH-D, was collected and evaporated to dryness under $\mathrm{N}_{2}$. The residue was dissolved in exactly $1 \mathrm{ml}$ ethanol for further assay. Of this, $0.5 \mathrm{ml}$ was assayed for ${ }^{3} \mathrm{H}$ to assess the recovery of 25-OH-D during extraction and chromatography (for this purpose, $1,000 \mathrm{dpm}$ of $\left[{ }^{3} \mathrm{H}\right] 25-\mathrm{OH}-\mathrm{D}_{3}$ in 10 
$\mu l$ ethanol had been added to the $0.5 \mathrm{ml}$ serum sample before extraction). The recovery was approximately $95 \%$ (range, $87-100 \%$ ).

The competitive binding assay was performed as follows. The samples to be assayed, dissolved in ethanol, were each added to one of a series of test tubes, as were standard amounts of pure unlabeled 25-OH- $\mathrm{D}_{3}$ varying from 0.1 to 10 ng per tube. All samples were asssayed in duplicate. To assess nonspecific binding, tubes containing $400 \mathrm{ng}$ of unlabeled 25-OH-D $\mathrm{D}_{3}$ were also prepared. After evaporating the ethanol, $0.002 \mathrm{nmol}$ (approximately 30,000 dpm) of $\left[{ }^{3} \mathrm{H}\right] 25-\mathrm{OH}-\mathrm{D}_{3}$ in $100 \mu \mathrm{l}$ ethanol was added to each tube, followed by $1 \mathrm{ml}$ of human whole serum diluted 1:4,000 with PBS. After incubation on ice for $60 \mathrm{~min}, 0.2 \mathrm{ml}$ dextran-coated charcoal and $0.2 \mathrm{ml}$ PBS were added, followed by $20 \mathrm{~min}$ further incubation. The mixtures were centrifuged for $10 \mathrm{~min}$ at $1,500 \mathrm{rpm}$ at $4^{\circ} \mathrm{C}$. Exactly $1 \mathrm{ml}$ of each supernate was transferred to a scintillation vial, mixed with $10 \mathrm{ml}$ of ScintiVerse (Fisher Scientific Co., Pittsburgh, Pa.), and ${ }^{3} \mathrm{H}$ was assayed in a Packard model 3003 liquid scintillation spectrometer (Packard Instrument Co.). Calculations were made on a Wang model $700 \mathrm{~A}$ calculator by the logit$\log$ method.

Approximately $50 \%$ of the $\left[{ }^{3} \mathrm{H}\right] 25-\mathrm{OH}-\mathrm{D}_{3}$ was bound to binding protein in the absence of added unlabeled 25-OH-D. Nonspecific binding was approximately $5 \%$. There was good agreement in the paired values obtained with samples assayed in duplicate. Thus, the values for each of 20 duplicate assays differed from the mean values for each duplicate pair by an average of $6.5 \pm 4.0 \%$ (SD). The assay was able to effectively measure 25-OH-D in amounts of from 0.2 to 5 ng per assay tube.

Serum samples. Samples were obtained from adult men and women with normal medical histories and physical examinations. Samples were obtained also from patients with hypercholesterolemia and (or) hypertriglyceridemia attending a lipid research clinic at this medical center. These patients were studied because their samples were readily available because the clinic is under the overall direction of one of the authors. Most of these patients were healthy except for the presence of hyperlipidemia; the latter was defined, for these purposes, as indicated previously (18).

Samples were obtained as well from five patients with chronic liver disease and from nine patients with chronic renal disease. The former patients were all diagnosed as having cirrhosis of the liver. Four of these patients were studied while hospitalized for their liver disease. All five patients had clinical and laboratory evidence of hepatocellular dysfunction; the mean serum albumin level was 2.9 $\mathrm{g} / \mathrm{dl}$. The patients with renal disease were all being treated with chronic hemodialysis for renal failure. The samples were collected just before the start of a dialysis treatment. The mean serum calcium level in the nine patients was $8.7 \mathrm{mg} / \mathrm{dl}$ (range, 7.2-9.7).

Blood was obtained from six patients with symptomatic Paget's disease. Three of the patients were being treated with mithramycin, and had mild hypocalcemia (calcium levels of $7.9-8.5 \mathrm{mg} / \mathrm{dl}$ ) as a consequence of therapy. The other three patients were normocalcemic.

Samples were obtained from three patients with hypoparathyroidism who were taking large doses of oral supplements of vitamin $D_{2}(50,000-100,000$ IU per day). Two of the patients had clinical evidence of vitamin $D$ toxicity and hypercalcemia (calcium levels of 21 and $12.1 \mathrm{mg} / \mathrm{dl}$, respectively) at the time of sample collection. One patient was normocalcemic (calcium, $10.1 \mathrm{mg} / \mathrm{dl}$ ) and well. A sample was also obtained from a patient with primary hyperparathyroidism (calcium, $14.1 \mathrm{mg} / \mathrm{dl}$ ) before surgical removal of a parathyroid adenoma. In all cases, after clotting of the venous blood samples, sera were separated by centrifugation and stored at $-20^{\circ} \mathrm{C}$ until analyzed.

DBP-depleted serum. Human serum was depleted of DBP by binding the DBP to Sepharose containing covalently bound rabbit antibodies against human DBP. Partially purified immunoglobulin $G$ was prepared from a sample of the monospecific rabbit anti-human DBP antiserum by precipitating twice at $4^{\circ} \mathrm{C}$ that fraction obtained between 0 and $33 \%$ saturation with $\left(\mathrm{NH}_{4}\right)_{2} \mathrm{SO}_{4}$. $\mathrm{CNBr}$-activated Sepharose $4 \mathrm{~B}$ was purchased from Pharmacia Fine Chemicals. $60 \mathrm{mg}$ of immunoglobulin $\mathrm{G}$ was coupled to Sepharose (dry weight $3 \mathrm{~g}$ ) according to the instructions of the supplier (yield of coupled immunoglobulin, about 90\%). The antiDBP-substituted Sepharose was suspended in PBS containing $0.1 \% \mathrm{NaN}_{3}$. Nonimmune rabbit immunoglobulin $\mathrm{G}$ was also prepared and coupled to Sepharose to provide a control preparation of immunoglobulin-substituted Sepharose.

DBP-depleted serum was prepared by incubating $3 \mathrm{~g}$ of anti-DBP-substituted Sepharose (wet weight) with $1 \mathrm{ml}$ of human whole serum for $3 \mathrm{~h}$ at $4^{\circ} \mathrm{C}$. After centrifuging the mixture for $10 \mathrm{~min}$ at $5,000 \mathrm{rpm}$ at $4^{\circ} \mathrm{C}$, the resulting supernate was concentrated by ultrafiltration (Minicon concentrators A-25, Amicon Corp., Lexington, Mass.); the sample was then adjusted to the original total protein concentration in the starting serum. A control sample was prepared by identical treatment of a second $1 \mathrm{ml}$ of whole serum with the control preparation of immunoglobulin-substituted Sepharose. These serum samples were used for immunodiffusion studies with anti-human Gc protein antiserum.

An experiment was conducted to study the effect of DBP depletion with the anti-DBP-substituted Sepharose on the content of protein-bound $\left[{ }^{3} \mathrm{H}\right] 25-\mathrm{OH}-\mathrm{D}_{3}$ in plasma that had been highly enriched with added $25-\mathrm{OH}-\mathrm{D}_{3} .30 \mathrm{ml}$ of human whole serum that had been diluted $1: 1,000$ (vol/vol) with PBS was added to a $40-\mathrm{ml}$ tube containing $0.3 \mathrm{nmol}$ of ${ }^{3} \mathrm{H}$ labeled $25-\mathrm{OH}-\mathrm{D}_{3}$ in $300 \mu \mathrm{l}$ ethanol and incubated for $2 \mathrm{~h}$ at $4^{\circ} \mathrm{C}$. After removal of two $1-\mathrm{ml}$ portions for radioassay, $7 \mathrm{ml}$ of dextran-coated charcoal was added to the remaining $28 \mathrm{ml}$ to bind and remove $\left[{ }^{3} \mathrm{H}\right] 25-\mathrm{OH}-\mathrm{D}_{3}$ which was not protein bound (i.e., "free"). The mixture was Vortex mixed, centrifuged for $15 \mathrm{~min}$ at $2,000 \mathrm{rpm}$ at $4^{\circ} \mathrm{C}$, and radioassayed for ${ }^{3} \mathrm{H}$. Of the $\left[{ }^{3} \mathrm{H}\right] 25-\mathrm{OH}-\mathrm{D}_{3}$ originally added to the diluted serum (estimated to represent a molar excess of approximately $25-30 \%$ as compared to the total serum immunoreactive DBP present), $39 \%$ was found remaining in the diluted serum after dextran-coated charcoal treatment, presumably representing $\left[{ }^{3} \mathrm{H}\right] 25-\mathrm{OH}-\mathrm{D}_{3}$ tightly bound to DBP. The molar ratio of protein-bound $\left[{ }^{3} \mathrm{H}\right] 25-\mathrm{OH}-\mathrm{D}_{3}$ to DBP in this sample (which was called " $\left[{ }^{3} \mathrm{H}\right] 25-\mathrm{OH}-\mathrm{D}_{3}$-enriched serum") was estimated to be approximately 0.5 .

About $1 \mathrm{~g}$ (wet weight) of anti-DBP-substituted Sepharose was suspended in $5 \mathrm{ml}$ of PBS. $0.5 \mathrm{ml}$ of this suspension was added to $1 \mathrm{ml}$ of the $\left[{ }^{3} \mathrm{H}\right] 25-\mathrm{OH}-\mathrm{D}_{3}$-enriched serum, and the mixture was incubated for $2 \mathrm{~h}$ at $4^{\circ} \mathrm{C}$ and then centrifuged for $15 \mathrm{~min}$ at $2,000 \mathrm{rpm}$ at $4^{\circ} \mathrm{C}$. Exactly $1 \mathrm{ml}$ of the supernate was assyed for its ${ }^{3} \mathrm{H}$ content as described above (for the assay for 25-OH-D). The experiment was carried out in duplicate, together with simultaneous duplicate control experiments carried out in the same manner but using the control immunoglobulin-substituted Sepharose instead of the anti-DBP-substituted Sepharose. Almost identical results were obtained with each member of the duplicate pairs, and the results were expressed as mean values.

Comparative immunology. The immunoreactivity of the rabbit anti-human DBP antiserum with serum samples from 


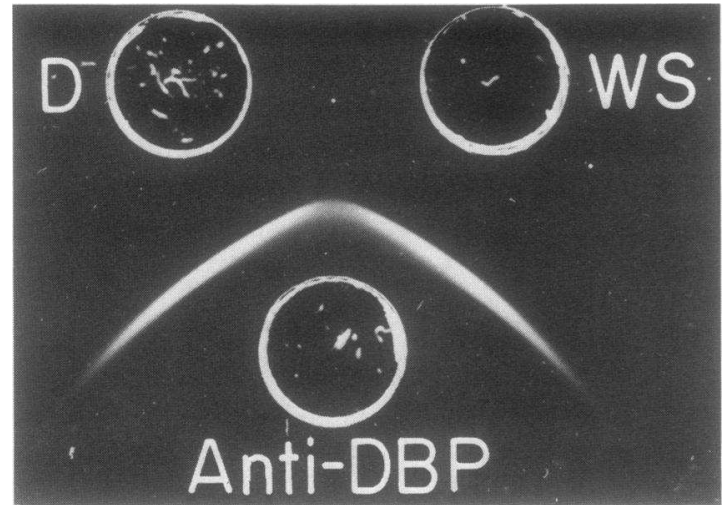

Figure 2 Immunodiffusion for $24 \mathrm{~h}$ of human whole serum (WS) (diluted 1:1 with PBS) and of the purified human DBP preparation (D) $(0.25 \mathrm{mg} / \mathrm{ml}$ in $\mathrm{PBS})$ against the monospecific rabbit antiserum prepared against DBP.

other vertebrate species was explored by double immunodiffusion in gel. Lyophilized normal sera from monkey, cow, swine, goat, sheep, deer, horse, cat, dog, hamster, guinea pig, pigeon, turkey, duck, and chicken were purchased from Cappel Laboratories, Inc., Downingtown, Pa. Sera from rat and mouse were obtained directly from normal animals. The presence or absence of immunological cross-reactivity was assessed qualitatively from the immunoprecipitin lines which were (or were not) observed.

Other methods and materials. Analytical (disc) polyacrylamide gel electrophoresis was performed according to two different procedures. Procedure 1 was identical to that employed previously with purified DBP (1) and used a $7 \%$ acrylamide gel (gel length $7 \mathrm{~cm}$ ) without a concentrating gel, with a continuous buffer system of Tris-glycine-HCl, pH 8.1. Procedure 2 employed a $7 \%$ acrylamide gel of 10 cm length without a concentrating gel, with a discontinuous buffer system (Tris-glycine electrode buffer, $\mathrm{pH} 8.3$, and Tris$\mathrm{HCl}$ gel buffer, $\mathrm{pH}$ 8.9) as described by Davis (19).

Double immunodiffusion in gel was carried out by the method of Ouchterlony (20) using gels prepared from $1 \%$ agarose in $0.02 \mathrm{M}$ potassium phosphate buffer, $\mathrm{pH} 7.2$, containing $0.15 \mathrm{M} \mathrm{NaCl}$ and $0.01 \% \quad \mathrm{NaN}_{3}$. 20- $\mu$ l samples were usually applied per well. After immunoreaction for 24-48 h, the gels were examined under dark-field illumination. For staining, the gels were washed for 3 days with PBS $\left(+0.02 \% \mathrm{NaN}_{3}\right)$ and then with distilled water overnight before drying in air. Gels were stained with $0.2 \%$ (wt/vol) Coomassie Brilliant Blue in 5\% methanol-15\% trichloroacetic acid (vol/vol) for 5-10 min, destained with $5 \%$ methanol$7.5 \%$ acetic acid for $24 \mathrm{~h}$, and then dried in air.

Protein concentration was measured by the method of Lowry et al. (21), using human serum albumin as a standard.

${ }^{3} \mathrm{H}$-Labeled 25-OH-D 3 (25-hydroxy [26,27-methyl $\left.-{ }^{3} \mathrm{H}\right]$ chole(alciferol, $6.9 \mathrm{Ci} / \mathrm{mmol}$ ) was purchased from Amersham/ Searle Corp., Arlington Heights, Ill. Rabbit antiserum against human Gc protein was purchased from Behring Diagnostics. Dextran-coated charcoal consisted of $0.05 \%$ Dextran T-70 (Pharmacia Fine Chemicals) and 0.5\% Norit A (Fisher Scientific Co.) in PBS.

\section{RESULTS}

Anti-human DBP antiserum. The first antiserum obtained after immunization if a rabbit with the purified DBP preparation was not monospecific, but showed a second contaminating precipitin line on double immunodiffusion or on immunoelectrophoresis (Fig. 1). This indicated that although the purified DBP preparation was homogeneous in the analytical ultracentrifuge and showed only a single band of protein on sodium dodecyl sulfate-disc gel electrophoresis and on polyacrylamide disc gel electrophoresis by procedure 1 (1), it nonetheless contained another protein as a trace impurity that was significantly antigenic. This contaminating protein was immunologically identified as human $\alpha_{1}$-antitrypsin (see Methods).

A monospecific anti-human DBP antiserum was subsequently raised in rabbits by injecting them with precipitin lines prepared by immunoelectrophoresis, containing DBP and rabbit antibody against DBP. This antiserum gave a single precipitin line when tested against either the purified DBP preparation or against human whole serum by immunodiffusion, and the lines obtained in these tests showed a reaction-of-identity with each other (Fig. 2).

Confirmatory evidence that the antibodies in the anti-DBP antiserum were indeed directed against the protein in human plasma responsible for the transport of $25-\mathrm{OH}-\mathrm{D}_{3}$ was obtained by treating $\left[{ }^{3} \mathrm{H}\right] 25-\mathrm{OH}-\mathrm{D}_{3}$ enriched serum with anti-DBP-substituted Sepharose, as described under Methods. This treatment resulted in the removal of $86 \%$ of the radioactivity $\left({ }^{3} \mathrm{H}\right)$ from the serum, presumably mainly due to the binding of the $\left[{ }^{3} \mathrm{H}\right] 25-\mathrm{OH}-\mathrm{D}_{3}$-DBP complex to the specific antibodies against DBP that were coupled to the Sepharose. In contrast, treatment of the same $\left[{ }^{3} \mathrm{H}\right] 25$ $\mathrm{OH}-\mathrm{D}_{3}$-enriched serum with control immunoglobulinsubstituted Sepharose under the identical conditions resulted in the loss of only $25 \%$ of the ${ }^{3} \mathrm{H}$ from the serum, reflecting nonspecific binding of $\left[{ }^{3} \mathrm{H}\right] 25-\mathrm{OH}-\mathrm{D}_{3}$ $( \pm \mathrm{DBP})$ to the Sepharose and (or) the glassware. Since highly diluted $\left[{ }^{3} \mathrm{H}\right] 25-\mathrm{OH}-\mathrm{D}_{3}$-enriched serum was used in these experiments, this degree of nonspecific binding is not surprising. It can be calculated that of the ${ }^{3} \mathrm{H}$ radioactivity not removed by nonspecific binding, $81 \%$ was specifically removed by the anti-DBP-substituted Sepharose under the conditions employed.

Radioimmunoassay: characteristics and results. Fig. 3 shows the displacement of ${ }^{125}$ I-DBP from antiDBP antibody by increasing amounts of unlabeled human DBP. Identical curves were obtained with various dilutions of purified DBP or whole serum obtained from normal humans. The radioimmunoassay as shown was able to effectively measure DBP in amounts of 1-10 ng of unlabeled DBP per assay tube.

DBP levels were measured by radioimmunoassay in serum samples collected from 13 normal adults. All samples were assayed in duplicate, and the intra- 
assay agreement, as determined by the agreement in the paired values obtained with each of the 13 duplicate pairs, was $7.9 \pm 6.8 \%$ (mean $\pm \mathrm{SD}$ ). The level of DBP observed in these normal sera was $460 \pm 59$ $\mu \mathrm{g} / \mathrm{ml}($ mean $\pm \mathrm{SD}$ ) with a range of $339-537 \mu \mathrm{g} / \mathrm{ml}$.

These data indicated that the concentration of immunoreactive DBP in serum was relatively high and suggested that a simpler immunoassay might be suitable for subsequent (and more extensive) clinical studies. A RID assay was, accordingly, developed for this purpose.

Radial immunodiffusion assay: characteristics. A simple RID assay for DBP was developed, as described under Methods, which provided an effective immunoassay for DBP in amounts of $0.2-0.8 \mu \mathrm{g}$ of DBP. The results obtained with the RID assay agreed well with those of the radioimmunoassay. Thus, the values obtained by RID assay on the same 13 samples of serum from normal subjects differed from the values obtained by radioimmunoassay by $5.9 \pm 3.2 \%$ (mean $\pm \mathrm{SD})$.

The intra-assay agreement in the RID assay was determined from the results of the first 50 duplicate pairs of serum samples analyzed. The values for each of the duplicate assays differed from the mean values for each duplicate pair by an average of $0.4 \pm 0.7 \%$ (SD) (range, 0-2\%). The interassay (between assay) agreement was estimated from the results obtained by repeated assay of the same sample of serum in each of several assay runs. Serum from a normal subject was diluted 1:4 with PBS, divided into several small portions, and stored at $-20^{\circ} \mathrm{C}$. During a 2 -mo period, portions were assayed in duplicate in six different assay runs. The mean $( \pm S D)$ level of DBP observed for the sample was $439 \pm 5 \mu \mathrm{g} / \mathrm{ml}$.

The recovery of pure DBP added to serum before RID assay (see Methods) was $96.3 \pm 1.2 \%$ (mean \pm SD). In addition, identical immunoreactivity was observed in the RID assay with samples of purified holoDBP (DBP containing bound 25-OH-D $\mathrm{D}_{3}$ ) and apoDBP (DBP without bound ligand).

Serum DBP and 25-OH-D concentrations. The DBP levels determined by the RID assay in samples obtained from normal and diseased subjects are summarized in Table I. Some of the same serum samples were also assayed for their concentration of 25-OH-D; the results of these assays are also summarized in Table I.

The mean $( \pm$ SD) DBP level observed in 35 normal subjects was $422 \pm 27 \mu \mathrm{g} / \mathrm{ml}$. The levels observed in men did not differ from those in women. Generally, similar values were observed in 66 hyperlipidemic men and women, although the mean value observed for the hyperlipidemic subjects $(446 \mu \mathrm{g} / \mathrm{ml})$ was slightly $(P<0.05)$ higher than that of the normal subjects. No differences were observed between patients with

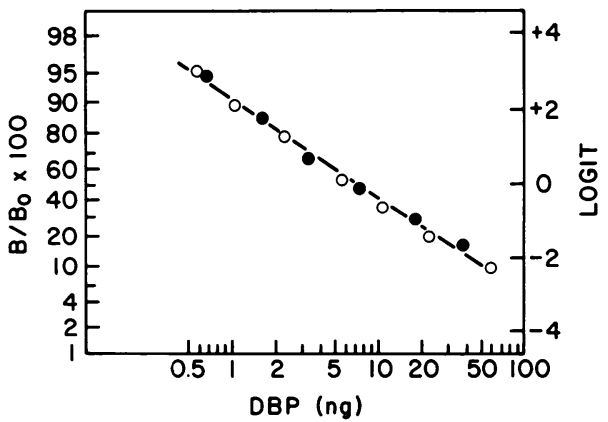

Figure 3 Radioimmunoassay standard curve for human DBP, comparing the results obtained with purified DBP $(O)$ with those obtained with varying dilutions of human whole serum (1). A sample of whole serum from a normal subject was assayed in duplicate to determine the level of DBP. A series of dilutions was then prepared to cover the range of amounts of DBP being assayed with the purified protein preparation. The results are shown as the logit transform of the response variate vs. amount of DBP on a logarithmic scale. Thus, in this figure, the DBP content of serum calculated for each dilution is plotted against 100 $\times \mathrm{B} / \mathrm{B}_{0}$, where $\mathrm{B}_{0}={ }^{125} \mathrm{I}-\mathrm{DBP}$ bound in the absence of added unlabeled DBP and $\mathrm{B}={ }^{125} \mathrm{I}-\mathrm{DBP}$ bound in the presence of added unlabeled DBP.

different types of hyperlipidemia. The 25-OH-D concentrations found in seven normal and in six hyperlipidemic subjects (mean values of 22.3 and 17.6 $\mathrm{ng} / \mathrm{ml}$, respectively) were comparable to the normal values for serum 25-OH-D reported by others (12, 22-26).

Patients with renal failure and with Paget's disease, not taking supplemental vitamin $\mathrm{D}$, had normal serum levels of both DBP and 25-OH-D. One patient with chronic renal disease was taking supplemental vitamin $\mathrm{D}_{2}, 50,000$ IU per day. This patient had a serum 25OH-D level of $112 \mathrm{ng} / \mathrm{ml}$, with a normal level of DBP $(419 \mu \mathrm{g} / \mathrm{ml})$.

Five patients with cirrhosis of the liver had markedly $(P<0.01)$ reduced serum levels of both DBP and 25-OH-D.

Two patients with vitamin $\mathrm{D}$ intoxication showed dramatically elevated serum levels of 25-OH-D (approximately 10 times the normal level); their DBP levels were, however, essentially normal. For one of these two hypercalcemic patients (DBP, $515 \mu \mathrm{g} / \mathrm{ml}$; $25-\mathrm{OH}-\mathrm{D}, 336 \mathrm{ng} / \mathrm{ml}$ ), frozen serum was available that had been collected $2 \frac{1}{2}$ mo earlier, at a time when she was mildly hypocalcemic (calcium, $8.6 \mathrm{mg} / \mathrm{dl}$ ). A DBP level of $470 \mu \mathrm{g} / \mathrm{ml}$ and a 25-OH-D level of $138 \mathrm{ng} / \mathrm{ml}$ was observed with this sample. A third sample was collected from this patient 2 mo after her episode of vitamin D intoxication, when her serum calcium level was normal $(10.1 \mathrm{mg} / \mathrm{dl})$. The observed levels of DBP and 25-OH-D in this sample were $567 \mu \mathrm{g} / \mathrm{ml}$ and $130 \mathrm{ng} / \mathrm{ml}$, respectively. Finally, a patient with primary hyperparathyroidism and hypercalcemia was ob- 
TABLE I

DBP and 25-OH-D Concentrations in Human Serum

\begin{tabular}{|c|c|c|c|c|c|c|c|c|}
\hline \multirow[b]{2}{*}{ Subjects } & \multirow[b]{2}{*}{ Sex } & \multirow{2}{*}{$\begin{array}{c}\text { Age } \\
\text { range } \ddagger\end{array}$} & \multicolumn{3}{|c|}{ DBP Concentration } & \multicolumn{3}{|c|}{ 25-OH-1) Concentration } \\
\hline & & & $n \S$ & Mean \pm SD & Range & $n \S$ & Mean \pm SD & Range \\
\hline & & $y r$ & \multicolumn{3}{|c|}{$\mu g / m l$} & \multicolumn{3}{|c|}{$n g / m l$} \\
\hline Normal & $\mathbf{M}$ & $23-70$ & 24 & $423 \pm 29$ & $355-473$ & $\begin{array}{c}7 \\
(4 \mathrm{M}, 3 \mathrm{~F})\end{array}$ & $22.3 \pm 9.2$ & $13.5-39.0$ \\
\hline Normal & $\mathrm{F}$ & $14-58$ & 11 & $419 \pm 20$ & $393-464$ & & & \\
\hline Hyperlipidemic & $\mathbf{M}$ & $24-67$ & 55 & $443 \pm 41$ & $354-549$ & $\begin{array}{c}6 \\
(4 M, 2 F)\end{array}$ & $17.6 \pm 10.3$ & $5.1-31.4$ \\
\hline Hyperlipidemic & $\mathrm{F}$ & $29-72$ & 11 & $460 \pm 61$ & $377-551$ & & & \\
\hline Chronic liver disease & $M+F$ & $40-74$ & 5 & $202 \pm 49$ & $148-262$ & 5 & $2.6 \pm 1.9$ & $0.6-5.4$ \\
\hline Chronic renal disease & $M+F$ & $19-71$ & 9 & $418 \pm 72$ & $286-524$ & $4 \pi$ & $23.4 \pm 6.9$ & $15.7-31.4$ \\
\hline Paget's disease & $\mathrm{M}+\mathrm{F}$ & $44-71$ & 6 & $432 \pm 21$ & $410-466$ & 6 & $20.9 \pm 4.0$ & $16.8-25.2$ \\
\hline \multicolumn{9}{|l|}{$\begin{array}{l}\text { Hypoparathyroid } \\
\text { + Vitamin D:" }\end{array}$} \\
\hline Hypercalcemic & $\mathrm{F}$ & 40,43 & 2 & 422 & 329,515 & 2 & 286. & 236,336 \\
\hline Normocalcemic & M & 15 & 1 & 494 & & 1 & 100 & \\
\hline $\begin{array}{l}\text { Primary hyperpara- } \\
\text { thyroidism }\end{array}$ & $\mathbf{M}$ & 46 & 1 & 503 & & 1 & 15.5 & \\
\hline
\end{tabular}

$* \mathrm{M}=$ male; $\mathrm{F}=$ female.

$\$$ For the subjects whose DBP levels were assayed.

$\S n=$ number of subjects.

"Oral vitamin $D_{2}, 50,000-100,000 \mathrm{U}$ per day.

I A fifth patient, taking oral vitamin $\mathrm{D}_{2}$, had $112 \mathrm{ng} / \mathrm{ml}$.

served to have a DBP level of $503 \mu \mathrm{g} / \mathrm{ml}$ and a 25 $\mathrm{OH}-\mathrm{D}$ level of $15.5 \mathrm{ng} / \mathrm{ml}$. These data indicate that major changes can occur in the serum levels of 25$\mathrm{OH}-\mathrm{D}$ and calcium with very little or no associated changes occurring in the serum concentration of DBP.

Identity of DBP and Gc protein. Daiger et al. (2) have reported genetic evidence for the identity of Gc protein with the plasma-binding protein for vitamin D. Accordingly, an experiment was conducted in which the monospecific anti-DBP antiserum and commercially obtained anti-Gc antiserum were studied together by double immunodiffusion in gel against human whole serum. A single precipitin line was obtained between each antiserum and whole serum, and the precipitin lines obtained with the two antisera showed a complete reaction-of-identity with each other (Fig. 4).

Further evidence for the conclusion that DBP and Gc protein are the same protein was obtained by studies with DBP-depleted serum. Human whole serum was depleted of DBP by binding the DBP to anti-DBP-substituted Sepharose, as described under Methods. The DBP level of the serum before depletion was estimated as $0.45 \mathrm{mg} / \mathrm{ml}$ by RID assay. After treatment with the anti-DBP-substituted Sepharose, the DBP level was found (RID assay) to be less than $0.045 \mathrm{mg} / \mathrm{ml}$, indicating that at least $90 \%$ of the immunoreactive DBP had been removed.

Untreated human whole serum and DBP-depleted serum were diluted serially with PBS and studied by immunodiffusion for immunoreactivity against commercial anti-Gc antiserum. Precipitin lines were observed (after $48 \mathrm{~h}$ of double diffusion) between whole serum and anti-Gc antiserum at dilutions of whole serum of up to $1: 7(\mathrm{vol} / \mathrm{vol})$. No precipitin line was observed between undiluted (or diluted) DBP-depleted serum and anti-Gc antiserum. Thus, the DBPdepleted serum contained less than one-eighth of the level of immunoreactive $\mathrm{Gc}$ protein found in untreated whole serum.

Treatment of whole serum with control immunoglobulin-substituted Sepharose resulted in no decrease in the observed level of DBP (estimated by RID assay) or in the approximate level of $\mathrm{Gc}$ protein (estimated by immunodiffusion with serial dilutions of the treated serum).

Gc proteins have $\alpha$-mobility on electrophoresis $(27,28)$, whereas we have previously reported (1) that 
the purified DBP preparation displayed mobility similar to that of plasma albumin. To explore this potential discrepancy, polyacrylamide disc gel electrophoresis was carried out under two different sets of conditions. When electrophoresis was carried out under the previously used conditions (procedure 1), a single band of protein was again observed, with mobility similar to that of plasma albumin. However, when procedure 2 (see Methods) was used, the purified DBP preparation showed $\alpha$-mobility, and two very slightly separated bands of protein were observed (Fig. 5). Thus, the electrophoretic mobility of DBP, relative to other plasma proteins, appears to be dependent upon the conditions employed. Under appropriate conditions, the purified DBP showed both the $\alpha$-mobility and the microheterogeneity which have been observed by others with Gc protein (29).

Comparative immunology. Serum samples from the monkey, cow, swine, goat, sheep, deer, horse, cat, and dog produced immunoprecipitin lines when tested by immunodiffusion against the anti-human DBP antiserum. Serum samples from the rat, mouse, hamster, guinea pig, pigeon, turkey, duck, and chicken did not show immunoreactivity. Monkey serum showed relatively stronger immunoreactivity (against anti-human DBP antiserum) than did the sera from the other animals tested. When sera that were immunoreactive with anti-human DBP antiserum were tested for immunological identity with human serum, they all showed patterns of partial identity. Furthermore, monkey serum also showed patterns of partial identity with sera from the other animals.

\section{DISCUSSION}

This report describes the development of a specific radioimmunoassay and a simple and accurate radial

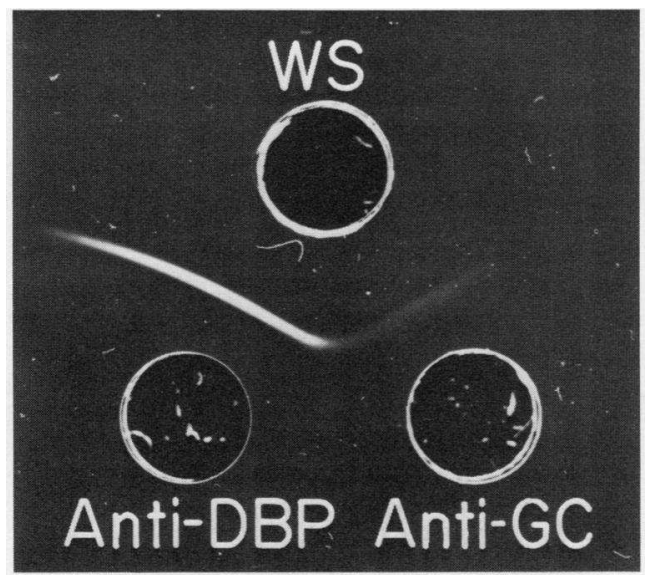

FIGURE 4 Immunodiffusion for $24 \mathrm{~h}$ of human whole serum (diluted 1:1 with PBS) opposite rabbit antisera against human DBP (Anti-DBP) and against human Gc protein (Anti-Gc).

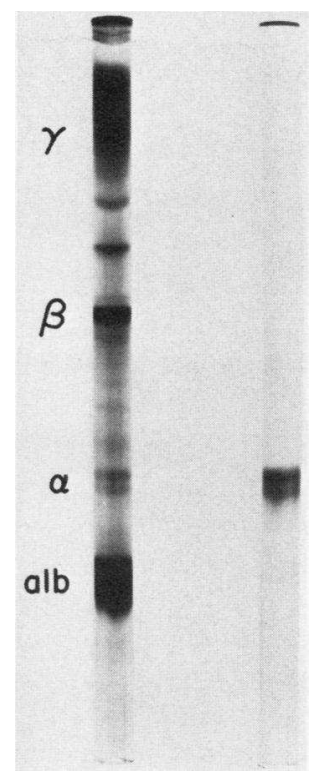

FIGURE 5 Polyacrylamide disc gel electrophoresis of samples of human whole serum (left) and of the purified DBP preparation (right), using Procedure 2, as described under Methods.

immunodiffusion assay for human DBP. The radioimmunoassay is two orders of magnitude more sensitive than the RID assay and effectively measures DBP in amounts of 1-10 $\mathrm{ng}$. In contrast, the RID assay provides an effective immunoassay for DBP in amounts of $0.2-0.8 \mu \mathrm{g}$. Thus, the two assays complement each other, since the RID assay is simpler to perform and more rapid, whereas the radioimmunoassay is much more sensitive and can detect much smaller quantities of DBP. The concentration of immunoreactive DBP in normal plasma is sufficiently high to permit the use of the RID assay for clinical studies involving large numbers of samples. If clinical or experimental conditions are observed, however, such that the concentration of DBP is below the range for the RID assay, the radioimmunoassay can then be employed. Moreover, the results obtained with the two immunoassays on the same samples were found to agree well with each other.

The immunoassays reported here used a monospecific antiserum against human DBP which was prepared in rabbits by injecting them with the precipitated antigen-antibody complex (as Laurell rocket precipitin lines) containing DBP and ant-DBP antibody. To verify that the antibodies in the monospecific antiserum were indeed directed against the protein in human plasma responsible for the transport of 25-OH-D, diluted serum was enriched with $\left[{ }^{3} \mathrm{H}\right] 25$ $\mathrm{OH}-\mathrm{D}_{3}$ and then treated with anti-DBP-substituted Sepharose. This treatment resulted in the removal of almost all $(86 \%)$ of the $\left[{ }^{3} \mathrm{H}\right] 25-\mathrm{OH}-\mathrm{D}_{3}$ from the 
serum. Furthermore, when excess antibody was used in the radioimmunoassay procedure, $97 \%$ of the radioiodinated purified DBP preparation was found to be antibody-bound. We have previously shown (1) that this same purified DBP preparation has a binding capacity of one molecule of $25-\mathrm{OH}-\mathrm{D}_{3}$ per molecule of protein. Taken together, these various data establish that the antibodies in the monospecific antiserum were directed against the transport protein for 25-OH-D and vitamin $\mathrm{D}$.

The mean $( \pm \mathrm{SD})$ serum DBP concentrations observed in 35 normal persons and in 66 hyperlipidemic persons were close to each other and were, respectively, $422 \pm 27$ and $446 \pm 45 \mu \mathrm{g} / \mathrm{ml}$. In molar terms, these mean DBP concentrations (approximately $8 \mu \mathrm{M}$ ) were markedly greater than the molar concentrations of 25-OH-D observed here in some of the normal and hyperlipidemic subjects (mean concentration approximately $50 \mathrm{nM}$ ) and as reported for normal subjects by others $(12,22-26)$. Thus, the concentration of DBP in serum appears to be of the order of 100 times or more the usual level of 25-OH-D in plasma, and of the order of 50 times the probable usual level of $25-\mathrm{OH}-\mathrm{D}$ and vitamin $\mathrm{D}(22,30)$. These findings are consistent with recent reports that rat (31) and human (32) serum contain relatively high binding (apacities for $25-\mathrm{OH}-\mathrm{D}_{3}$, representing, respectively, approximately 20 and 50 times the normal concentrations of circulating 25-OH-D. Most of plasma DBP circulates as apo-DBP, not containing a bound molecule of 25-OH-D or vitamin D. In this respect, vitamin $\mathrm{D}$ transport and DBP differ drastically from vitamin A transport and RBP, since RBP is secreted from the liver and circulates in plasma almost entirely as the retinol-RBP complex (i.e., as the holoprotein) $(3.3,34)$. The physiological significance, if any, of the large molar excess in serum of DBP, compared to 25-OH-D plus vitamin $\mathrm{D}$, remains to be defined.

DBP and 25-OH-D concentrations were determined in a limited number of patients with hypercalcemia (primary hyperparathyroidism and vitamin D intoxication), with mild hypocalcemia (chronic renal disease and Paget's disease under therapy with mithramycin), and with markedly elevated (to 10 times normal) serum 25-OH-D levels due to oral vitamin D supplementation. The results obtained (Table I) indicate that major changes can occur in the serum levels of 25-OH-D and calcium with very little or no associated changes occurring in the serum concentration of DBP. These findings strongly suggest that serum DBP concentration is not correlated with the serum levels of either 25-OH-D or of calcium, and that neither of these parameters plays an important role in the regulation of the metabolism of DBP. Further studies in larger series of subjects will be of interest to definitively examine these points.
Five patients with cirrhosis of the liver all showed markedly reduced levels of both DBP and of 25-OH-D. The very low 25-OH-D levels observed in these patients reflect the fact that the 25-hydroxy metabolite of vitamin $\mathrm{D}$ is formed from vitamin $\mathrm{D}$ in the liver (35). The low DBP levels found in these patients suggest that DBP is also produced in and secreted by the liver. These observations are, moreover, consistent with evidence that has been reported previously suggesting that the liver is the principal site of $\mathrm{Gc}$ protein synthesis $(36,37)$.

The DBP preparation used here had been isolated, as described previously (1), by an extensive sequence of procedures that resulted in a final yield of only approximately $4 \mathrm{mg}$ of purified DBP from a starting volume of 34 liters of plasma. Furthermore, the final DBP preparation appeared to have been purified approximately 13,000-fold from whole plasma, as estimated from the specific radioactivity of protein-bound $\left[{ }^{3} \mathrm{H}\right] 25-\mathrm{OH}-\mathrm{D}_{3}(1)$. The question therefore arises as to how these earlier findings can be reconciled with the results reported here of a mean normal DBP level of $422 \mu \mathrm{g} / \mathrm{ml}$, indicating that DBP represents more than $1 / 200$ th of the total protein in plasma.

We believe that the small yield and high degree of purification of DBP observed previously (1) resulted because of the fact that the DBP was identified (and was assayed for during protein fractionation procedures) by means of the bound tracer $\left[{ }^{3} \mathrm{H}\right] 25$ $\mathrm{OH}-\mathrm{D}_{3}$ that had been added to plasma before fractionation. More recent and ongoing experiments in our laboratory have demonstrated that some of the protein-fractionation procedures which were used previously (particularly chromatography on SPSephadex and Blue Sepharose 6B) separate holo-DBP (that is, DBP containing bound 25-OH-D $\mathrm{D}_{3}$ ) from apoDBP. Accordingly, it appears that our previous purification sequence selectively isolated a holo-DBPenriched sample of DBP. In studies currently in progress in our laboratory, DBP-purification procedures are being monitored by immunoassay, permitting the use of a simpler and shorter purification sequence than previously employed. In addition, the possibility should be considered that plasma DBP might consist of several different subspecies of molecules which are immunologically indistinguishable, but which differ with regard to their affinity for 25$\mathrm{OH}-\mathrm{D}_{3}$ and (or) for other vitamin $\mathrm{D}$ metabolites. The known molecular heterogeneity of Gc protein (29) (i.e. of DBP) lends potential credence to this possibility. If this were the case, then our earlier purification sequence might have selectively isolated that subspecies of DBP with the highest affinity for tracer 25-OH- $\mathrm{D}_{3}$. Of interest in this regard is the fact that our extensive purification procedure (1) apparently selectively isolated the Gc 1 protein (both fast and 
slow bands, Fig. 5), with concurrent loss of the relatively small amount of Gc 2 protein that would have been expected to be present in the pooled plasma from which the DBP was isolated. Another possibility is that DBP (or a subspecies of DBP) might normally be involved in the binding (and transport) of other unknown ligands, in addition to vitamin D-related steroids. Future studies will be required to explore these and other possibilities regarding the structural and (or) functional heterogeneity of plasma immunoreactive DBP.

Daiger et al. (2) recently reported genetic and electrophoretic evidence for the identity of Gc protein with the plasma binding protein for vitamin D. Before this report, the possible physiological function of $\mathrm{Gc}$ protein was not known. The Gc proteins have been investigated extensively as a marker for genetic studies during the past $15 \mathrm{yr}$. Gc proteins display genetic polymorphism, with three common phenotypes (Gc 1-1, Gc 2-1, and Gc 2-2) being found in somewhat varying proportions throughout the world $(27,28)$. These phenotypes reflect the fact that two alleles, $\mathrm{Gc}^{1}$ and $\mathrm{Gc}^{2}$, are found in all human populations. In almost all populations studied, $\mathrm{Gc}^{1}$ has been found to be more common than $\mathrm{Gc}^{2}$. Uncommon $\mathrm{Gc}$ allelic variants and phenotypes have also been observed. In a recent review (27), it was pointed out that published data regarding $\mathrm{Gc}$ phenotypes are available on more than 190 populations from all continents comprising a total of more than 75,000 individual specimens.

The studies reported here confirm and extend the work of Daiger et al. (2), and provide strong evidence that DBP and Gc protein are indeed the same protein. On immunodiffusion against whole serum, the line formed with the anti-DBP antiserum showed a complete reaction-of-identity with the line formed with commercial antiserum against Gc protein. Furthermore, serum that had been depleted of DBP by treatment with anti-DBP-substituted Sepharose was found to be depleted also of immunoreactivity against anti-Gc protein antiserum. In addition, the properties of our purified DBP preparation agree closely with those previously reported for Gc protein. Thus, the amino acid composition of purified DBP ( $\mathrm{l}$ ) is very similar to the reported amino acid composition of Gc proteins $(38,39)$. DBP was estimated to have a mol wt $\cong 52,000$ (1), similar to the reported average mol wt of $50,800 \pm 2,900$ for a highly purified Gc 2-2 preparation (38). As reported here, under appropriate conditions, purified DBP shows both the $\alpha$-mobility and the microheterogeneity (29) which are characteristic of $\mathrm{Gc}$ protein. The limited estimates available of the concentration of $\mathrm{Gc}$ protein in plasma $(37,40)$ are also roughly similar to the DBP levels in serum reported here. All of the available evidence thus sup- ports the conclusion that DBP and Gc protein are identical. In addition, two very recent reports (published after this paper was first submitted for publication) have presented virtually identical findings as observed in our studies on the isolation and partial characterization of the 25-OH-D-binding protein and on its immunological identity with Gc protein $(41,42)$. It will be of interest to try to explore in future studies whether or not differences in vitamin D metabolism might exist among persons with the different Gc phenotypes.

The comparative immunology study was conducted to qualitatively explore the degree of immunological specificity of DBP with regard to different species and mammalian orders. Previous studies of RBP demonstrated a high degree of immunological specificity within a given mammalian order (43). In contrast, the results reported here showed that sera from several different mammalian orders (including primates, artiodactyla, perissodactyla, and (arnivora) showed some immunoreactivity on immunodiffusion against the anti-human DBP antiserum. Moreover, all of the samples showed patterns of partial identity with the DBP in human whole serum. Thus, proteins immunologically similar to human DBP, presumably representing the DBP of that particular species, are present in sera from a number of mammalian species and orders.

\section{ACKNOWLEDGMENTS}

We are grateful to Doctors J. E. Smith and F. R. Smith for advice and assistance with some aspects of these studies, to Doctors R. Bilezikian, R. Canfield, G. Jacob, F. R. Smith, A. Seplowitz, and M. Balkin for providing samples from patients with different diseases for study, and to Mr. J. Muzicka for his technical assistance.

This work was supported by grant AM-05968 from the National Institutes of Health.

\section{REFERENCES}

1. Imawari, M., K. Kida, and DeW. S. Goodman. 1976. The transport of vitamin D and its 25-hydroxy metabolite in human plasma. Isolation and partial characterization of vitamin $\mathrm{D}$ and 25-hydroxyvitamin $\mathrm{D}$ binding protein. J. Clin. Invest. 58: 514-523.

2. Daiger, S. P., M. S. Schanfield, and L. L. CavalliSforza. 1975. Group-specific component (Gc) proteins bind vitamin D and 25-hydroxyvitamin D. Proc. Natl. Acad. Sci. U. S. A. 72: 2076-2080.

3. Imawari, M., K. Kida, and DeW. S. Goodman. 1976. Human vitamin $\mathrm{D}$ and 25-hydroxyvitamin $\mathrm{D}$ binding protein (DBP): Isolation and partial characterization. Clin. Res. 24: 458A. (Abstr.)

4. Muto, Y., and DeW. S. Goodman. 1972. Vitamin A transport in rat plasma. Isolation and characterization of retinol-binding protein. J. Biol. Chem. 247: 2533-2541.

5. Laurell, Carl-Bertil. 1966. Quantitative estimation of proteins by electrophoresis in agarose gel containing antibodies. Anal. Biochem. 15: 45-52. 
6. Weston, P. D. 1969. A specific antiserum to lysosomal cathepsin D. Immunology. 17: 421-428.

7. Poole, A. R., J. T. Dingle, A. K. Mallia, and DeW. S. Goodman. 1975. The localization of retinol-binding protein in rat liver by immunofluorescence microscopy. J. Cell Sci. 19: 379-394.

8. Miyachi, Y., J. L. Vaitukaitis, E. Nieschlag, and M. B. Lipsett. 1972. Enzymatic radioiodination of gonadotropins. J. Clin. Endocrinol. Metab. 34: 23-28.

9. Desbuquois, B., and G. D. Aurbach. 1971. Use of polyethylene glycol to separate free and antibody-bound peptide hormones in radioimmunoassays.J. Clin. Endocrinol. Metab. 33: 732-738.

10. Rodbard, D., W. Bridson, and P. L. Rayford. 1969. Rapid calculation of radioimmunoassay results. J. Lab. Clin. Med. 74: 770-781.

11. Mancini, G., A. O. Carbonara, and J. F. Heremans. 1965. Immunochemical quantitation of antigens by single radial immunodiffusion. Immunochemistry. 2: 235-254.

12. Haddad, J. G., and K. J. Chyu. 1971. Competitive protein-binding radioassay for 25-hydroxycholecalciferol. J. Clin. Endocrinol. Metab. 33: 992-995.

13. Bouillon, R., P. Van Kerkhove, and P. De Moor. 1976. Measurement of 25-hydroxyvitamin $\mathrm{D}_{3}$ in serum. Clin. Chem. 22: 364-368.

14. Edelstein, S., M. Charman, D. E. M. Lawson, and E. Kodicek. 1974. Competitive protein-binding assay for 25-hydroxycholecalciferol. Clin. Sci. Mol. Med. 46: 231240.

15. Belsey, R. E., H. F. DeLuca, and J. T. Potts, Jr. 1974. A rapid assay for 25-hydroxyvitamin $D_{3}$ without preparative chromatography. J. Clin. Endocrinol. Metab. 38: 1046-1051.

16. Bayard, F., P. Bec, and J. P. Louvet. 1972. Measurement of plasma 25-hydroxycholecalciferol in man. Eur. J. Clin. Invest. 2: 195- 198.

17. Holick, M. F., and H. F. DeLuca. 1971. A new chromatographic system for vitamin $\mathrm{D}_{3}$ and its metabolites: Resolution of a new vitamin $\mathrm{D}_{3}$ metabolite. J. Lipid Res. 12: 460-465.

18. Smith, F. R., R. B. Dell, R. P. Noble, and DeW. S. Goodman. 1976. Parameters of the three-pool model of the turnover of plasma cholesterol in normal and hyperlipidemic humans. J. Clin. Invest. 57: 137-148.

19. Davis, B. J. 1964. Disc electrophoresis. II. Method and application to human serum proteins. Ann. N. Y. Acad. Sci. 121: 404-427.

20. Ouchterlony, Ö. 1962. Diffusion-in-gel for immunological analysis. II. Prog. Allergy. 6: 30-154.

21. Lowry, O. H., N. J. Rosebrough, A. L. Farr, and R. J. Randall. 1951. Protein measurement with the Folin phenol reagent. J. Biol. Chem. 193: 265-275.

22. Haddad, J. G., and T. C. B. Stamp. 1974. Circulating 25-hydroxyvitamin D in man. Am. J. Med. 57: 57-62.

23. McLaughlin, M., P. R. Raggatt, A. Fairney, D. J. Brown, E. Lester, and M. R. Wills. 1974. Seasonal variations in serum 25 -hydroxycholecalciferol in healthy people. Lancet. I: 536-538.

24. Hahn, T. H., B. A. Hendin, C. R. Scharp, V. C. Boisseau, and J. G. Haddad, Jr. 1975. Serum 25-hydroxycalciferol levels and bone mass in children on chronic anticonvulsant therapy. N. Engl. J. Med. 292: 550-554.

25. Hillman, L. S., and J. G. Haddad. 1974. Human perinatal vitamin D metabolism I: 25-hydroxyvitamin D in maternal and cord blood. J. Pediatr. 84: 742-749.
26. Bouillon, R., J. Reynaert, J. H. Claes, W. Lissens, and P. De Moor. 1975. The effect of anticonvulsant therapy on serum levels of 25-hydroxy-vitamin D, calcium, and parathyroid hormone. J. Clin. Endocrinol. Metab. 41: 1130-1135.

27. Cleve, H. 1973. The variants of the group-specific component. A review of their distribution in human populations. Isr. J. Med. Sci. 9: 1133-1146.

28. Giblett, E. R. 1969. Genetic markers in human blood. In The Gc System. F. A. Davis Company, Philadelphia. 160-175.

29. Bearn, A. G., F. D. Kitchin, and B. H. Bowman. 1964. Heterogeneity of the inherited group-specific component of human serum. J. Exp. Med. 120: 83-91.

30. Smith, J. E., and DeW. S. Goodman. 1971. The turnover and transport of vitamin $\mathrm{D}$ and of a polar metabolite with the properties of 25-hydroxycholecalciferol in human plasma. J. Clin. Invest. 50: 2159-2167.

31. Haddad, J. G., and S. J. Birge. 1975. Widespread, specific binding of 25-hydroxycholecalciferol in rat tissues. J. Biol. Chem. 250: 299-303.

32. Haddad, J. G., L. Hillman, and S. Rojanasathit. 1976. Human serum binding capacity and affinity for 25hydroxyergocalciferol and 25-hydroxycholecalciferol. $J$. Clin. Endocrinol. Metab. 43: 86-91.

33. Goodman, DeW. S. 1974. Vitamin A transport and retinolbinding protein metabolism. Vitam. Horm. 32: 167-180.

34. Smith, F. R., and DeW. S. Goodman. 1971. The effects of diseases of the liver, thyroid, and kidneys on the transport of vitamin $\mathrm{A}$ in human plasma. J. Clin. Invest. 50: 2426-2436.

35. Ponchon, G., A. L. Kennan, and H. F. DeLuca. 1969. "Activation" of vitamin D by the liver. J. Clin. Invest. 48: 2032-2037.

36. Prunier, J. H., A. G. Bearn, and H. Cleve. 1964. Site of formation of the group-specific component and certain other serum proteins. Proc. Soc. Exp. Biol. Med. 115: 1005- 1007 .

37. Kitchin, F. D., and A. G. Bearn. 1965. Quantitative determination of the group specific protein in normal human serum. Proc. Soc. Exp. Biol. Med. 118: 304-307.

38. Cleve, H., J. H. Prunier, and A. G. Bearn. 1963. Isolation and partial characterization of the two principal inherited group-specific components of human serum. J. Exp. Med. 118: 711-726.

39. Simons, K., and A. G. Bearn. 1967. The use of preparative polyacrylamide-column electrophoresis in isolation of electrophoretically distinguishable components of the serum group-specific protein. Biochim. Biophys. Acta. 133: $499-505$.

40. Reinskou, T. 1968. The Gc system. Series Haematol. 1: $21-37$.

41. Haddad, J. G., Jr., and J. Walgate. 1976. 25-Hydroxyvitamin $\mathrm{D}$ transport in human plasma. Isolation and partial characterization of calcifidiol-binding protein. $J$. Biol. Chem. 251: 4803-4809.

42. Bouillon, R., H. Van Baelen, W. Rombauts, and P. De Moor. 1976. The purification and characterisation of the human-serum binding protein for the 25-hydroxycholecalciferol (transcalciferin). Identity with groupspecific component. Eur. J. Biochem. 66: 285-291.

43. Muto, Y., F. R. Smith, and DeW. S. Goodman. 1973. Comparative studies of retinol transport in plasma. J. Lipid Res. 14: 525-532. 